\title{
ANALISIS METODE PENGGALIAN PADA MATERIAL LUNAK DENGAN MENGGUNAKAN PC 2000 HINGGA PC 4000 DI TAMBANG LATI, PT BERAU COAL
}

\author{
Welly Turupadang, Ichsan Sebastian, Nur Alim K, Bagus Rachmad ${ }^{1)}$, Komang Yogatama ${ }^{2)}$ \\ ${ }^{1)}$ Departemen Geoteknik \& Hidrologi - Mine Planning \& Technical Services, PT Berau Coal \\ ${ }^{2)}$ Departemen Lati Mining Operation - Mine Operation \& Support, PT Berau Coal
}

\begin{abstract}
ABSTRAK
Tambang Lati merupakan bukaan pit terbesar yang dioperasikan oleh PT Berau Coal (PT BC) dengan target produksi batubara pada tahun 2019 sebesar 14,2 juta Metrik Ton (M/T) dan Stripping Ratio (SR) 12,5. Untuk memenuhi target produksi tersebut, maka diperlukan pengembangan lokasi baru dengan total luas bukaan sekitar 187 ha. Distribusi luasan tersebut meliputi $61 \%$ atau sekitar 114 ha merupakan area pengembangan pit berupa material lunak / rawa dengan estimasi volume yang harus dipindahkan sekitar 14 juta Bank Cubic Meter (BCM), sedangkan sisanya merupakan morfologi area perbukitan gelombang rendah - sedang, hal ini dicirikan adanya dataran luas dengan perbukitan di sekitarnya. Ketersediaan alat gali dan muat yang besar (PC 2000 - PC 4000) di Lati mengakibatkan jumlah material untuk kebutuhan timbunan perlapisan jalan maupun front loading di area rawa (layering) yang digunakan menjadi lebih besar dari perencanaan awal. Hal ini mempengaruhi Stripping Ratio (SR) yang sangat signifikan dan tingkat keekonomisan Tambang Lati PT Berau Coal. Evaluasi dilakukan dengan menggunakan data material insitu (tanah lunak / rawa) yang diperoleh dari hasil pemboran Standard Penetration Test (SPT). Penampang atau profil material lunak/ rawa dapat dikelompokkan berdasarkan data hasil pemboran ini, sehingga diperoleh distribusi penyebarannya dan dapat ditentukan secara vertikal maupun horizontal. Distribusi data penampang atau profil material lunak/rawa digunakan pada analisis geoteknik yang dikombinasikan terhadap aspek keselamatan dan operasional dari unit yang digunakan serta dilakukan percobaan langsung di lapangan selama 2 bulan pada lokasi yang acak. Penelitian ini mengevaluasi tingkat kestabilan lereng material lunak/endapan rawa, optimalisasi metode penggalian serta layering sehingga dapat mengakomodasi berbagai kepentingan, khususnya aspek keselamatan dan keekonomisan tambang. Hasil penelitian menunjukkan bahwa loading material lunak / rawa yang mengkombinasikan hasil kajian geoteknik dan aspek operasional dapat bersinergi sehingga operasional penambangan dapat dilakukan secara aman, efisien dan ekonomis dengan menggunakan alat besar (PC2000 - PC4000) yang tersedia di Lati Mine Operation.
\end{abstract}

Kata kunci : Tambang Lati, Tanah Lunak, Rawa, PT Berau Coal, Stripping Ratio, Standard Penetration Test, Loading rawa, PC 2000, PC 2500, PC 3600 dan PC 4000.

\begin{abstract}
Lati Mine Operation is the largest open-pit mining operated by PT Berau Coal (PT BC) with a coal production target in 2019 of 14.2 million Metric Tons (M / T) and Stripping Ratio (SR) 12.5. To meet the production target, it is necessary to develop a new location with a total open-pit area of around $187 \mathrm{ha} .61 \%$ or around 114 ha of the area are development zones consisting of 14 million Bank Cubic Meters (BCM) of soft materials, while the rest is the morphology of low-moderate hills, this is characterized by a vast plain surrounded by hills. The availability of large excavator and hauler equipment (PC 2000 - PC 4000) to move the overburden materials causes the amount of material for layering needs exceeds the initial plan. This condition will affect Stripping Ratio (SR), which has a significant effect on the economic level of Lati Mine. An evaluation is carried out using insitu data (soft materials) obtained from the results of the Standard Penetration Test (SPT) drilling. Cross section of the soft materials can be grouped by drilling data, so that distribution is obtained and can be vertically or horizontally determined at the Lati mine site. Cross-sectional or
\end{abstract}


soft materials profiles data distribution are then used in the geotechnical analysis combined with the safety and operational aspects of the used-units which had field trial for 1 month at many random locations. This study evaluated the stability of soft materials and the optimization of digging and layering methods so that it can accommodate various interests, especially the mining safety and economic aspects. The results show that soft materials loading which combines the results of geotechnical studies and operational aspects can synergize so that mining operations can be carried out safely, efficiently and economically by large equipment available in Lati Mine Operation.

Keywords : Lati Mine Operation, Soft Material, PT Berau Coal, Stripping Ratio, Standard Penetration Test, Soft Material Loading, PC 2000, PC 2500, PC 3600 and PC 4000.

\section{A. PENDAHULUAN}

PT Berau Coal merupakan perusahaan tambang batubara yang terletak di Tanjung Redeb, Kalimantan Timur. Pada tahun 2019 PT Berau Coal melakukan penambangan dengan target produksi sebesar 33 juta ton batubara, penambangan dilakukan pada tiga area tambang yaitu Lati Mine Operation, Sambarata Mine Operation dan Binungan Mine Operation. Salah satu kegiatan dalam aktivitas penambangan pada tambang terbuka yang dilakukan PT Berau Coal adalah melakukan kegiatan loading material lunak. Kegiatan loading material lunak merupakan proses pengangkutan material lunak, dimana dibutuhkan timbunan perlapisan jalan maupun front loading di area rawa (material layering) dari sisa blasting sebagai tambahan kekuatan daya dukung untuk menopang unit yang bekerja diatasnya.

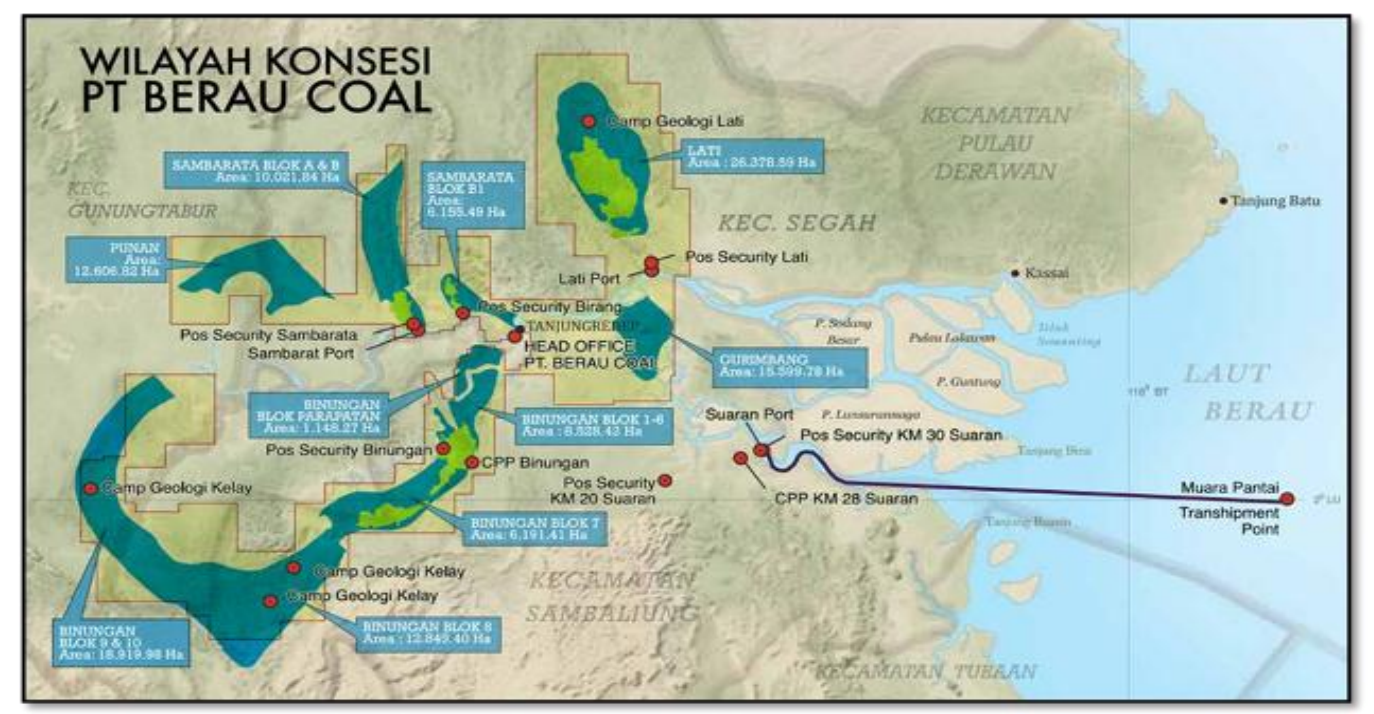

Gambar 1. Peta Konsesi PT. Berau Coal

Studi ini bertujuan untuk mengevaluasi tingkat kestabilan lereng material lunak/endapan rawa, optimalisasi metode penggalian serta layering sehingga dapat mengakomodasi berbagai kepentingan, khususnya aspek keselamatan dan keekonomisan tambang.

Penelitian ini dilakukan pada area tambang Lati dengan luas wilayah bukaan tahun 2019 sebesar 187 ha, dimana diantaranya \pm 114 ha merupakan wilayah pengembangan yang terdiri dari material lunak, dengan nilai Stripping Ratio 12.5. Keekonomisan tambang ini sangat berpengaruh terhadap metode penambangan material lunak, dimana $61 \%$ dari wilayah bukaan tambang merupakan material lunak, dengan estimasi volume material lunak instu yang akan di loading pada tahun 2019 sebesar 17.000.000 BCM. 
Metode penggalian rawa yang ada sebelumnya (menggunakan excavator sekelas PC 1250), mengakomodir beda tinggi dinding galian maksimum 3-5 $\mathrm{m}$ dan layering dengan ketebalan 1,5-2 $\mathrm{m}$ untuk mendapatkan perbandingan loading terhadap layering yaitu $1: 0,5$. Sedangkan unit yang beroperasi di Lati saat ini didominasi oleh PC 2000, PC 2500, PC 3600 dan PC 4000. Sehingga metode ini tidak lagi sesuai dengan kondisi bukaan tambang di Lati dan berpotensi menambah cost handling material lunak akibat dari peningkatan tebal layering dan pembatasan tinggi dinding galian. Diperlukan penambahan data pengeboran geoteknik serta re-analisis kestabilan lereng untuk menjelaskan kondisi material lunak secara terperinci sehingga dapat mengakomodir besaran spesifikasi unit yang dapat bekerja serta mengevalusi geometri lereng yang mungkin terbentuk berdasarkan soil properties aktual.

\section{B. METODOLOGI PENELITIAN}

Kondisi area development tambang Lati sebagian besar merupakan material lunak dan ex-disposal (redisturb) bekas penambangan sebelumnya. Dilakukan penambahan pengambilan data lapangan berupa pengeboran Standard Penetration Test (SPT) sebanyak 11 titik dan Dynamic Cone Penetrometer (DCP) sebanyak 7 titik di area material lunak yang masuk dalam rencana penambangan Lati. Data hasil pemboran digunakan sebagai dasar untuk melakukan analisis geotechnik terhadap beban unit yang akan bekerja, berdasarkan ground pressure yang dihasilkan oleh masing-masing alat gali muat (PC 2000, PC 3600 dan PC 4000) dan beda tinggi maksimum galian yang dapat dibentuk dengan mempertimbangkan maksimal tinggi kabin unit yang beroperasi.

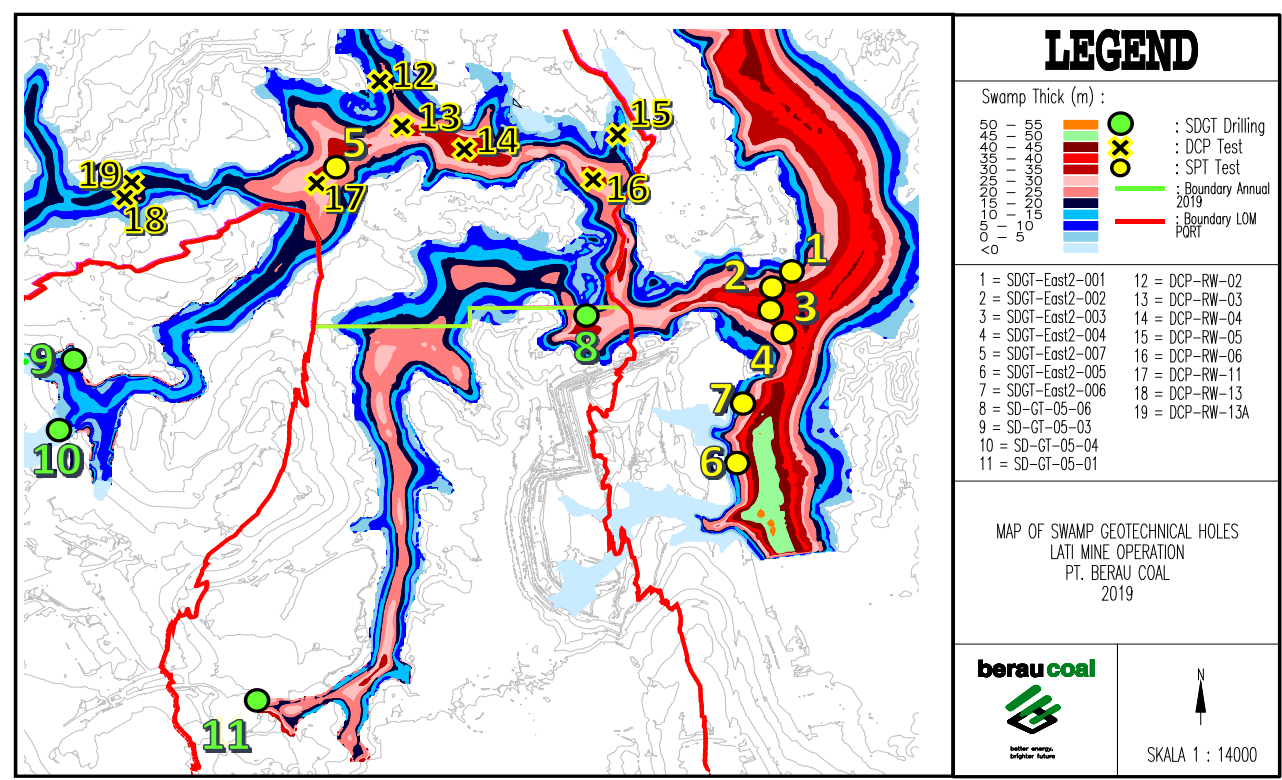

Gambar 2. Peta Lokasi Pemboran SPT dan DCP

\section{HASIL DAN PEMBAHASAN}

\section{C.1. Metode Lama, Loading Rawa Menggunakan PC 1250}

Metode penggalian material lunak sebelumnya mengatur teknis penggalian rawa sebagai berikut :

- Posisi alat loading berada pada elevasi atas pada material insitu dan berjarak $3 \mathrm{~m}$ atau lebih dari crest lereng bukan material tanah lunak

- Layering dilakukan dengan material keras (fresh blast) dengan ketebalan 1,5 hingga 2 meter. Beda tinggi antara track alat angkut ke crest lereng tidak lebih dari $3 \mathrm{~m}$. 
Setelah layering dilakukan, proses berikutnya yaitu melakukan loading kembali
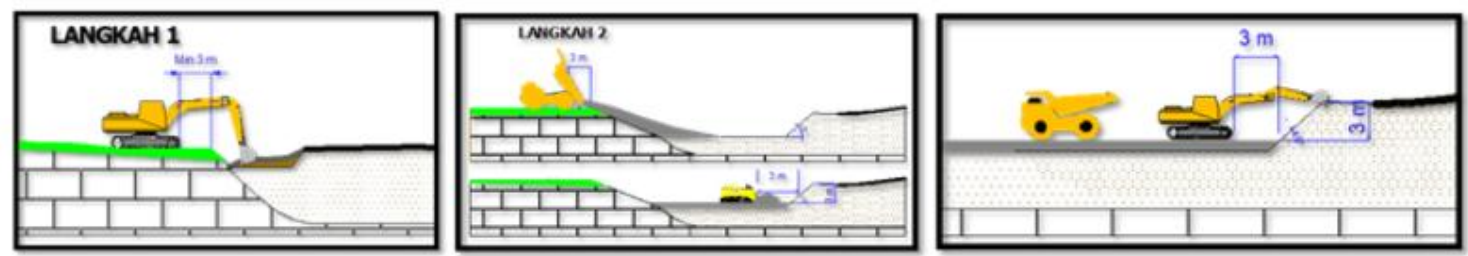

Gambar 3. Metode Loading Rawa menggunakan PC 1250 di PT. BC

Metode loading rawa menggunakan PC 1250 tidak aplikatif untuk diterapkan pada kondisi penambangan site Lati saat ini, hal ini dikarenakan pada tahun 2019 alat gali muat yang beroperasi di area Lati sebagian besar merupakan PC 2000, PC 2500, PC 3600 dan PC 4000 yang membutuhkan layering yang lebih besar dibanding PC 1250. Jika operasional tetap di lakukan dengan metode lama maka volume layering yang diharapkan memiliki ratio $1: 0,5$ tidak dapat terpenuhi, oleh karenanya perlu dilakukan analisis geoteknik guna mengetahui ketebalan minimum layering yang harus dibentuk untuk masing-masing alat gali muat yang bekerja pada area tersebut. Hasil analisis dapat menjadi acuan perhitungan tebal material layering yang dibutuhkan untuk luasan rawa tertentu dan menghindari terjadinya amblas untuk alat yang bekerja diarea Lati Mine Operation.

Tabel 1. Analisis ground pressure alat gali dan muat

\begin{tabular}{|c|c|c|c|c|c|}
\hline \multirow{2}{*}{ Type } & \multirow{2}{*}{ Product } & \multicolumn{2}{|c|}{ roda / track } & \multirow{2}{*}{$\left(\begin{array}{l}\mathrm{kd} / \mathrm{cm} 2) \\
\mathrm{GP}\end{array}\right.$} & \multirow{2}{*}{$\begin{array}{c}\Sigma \mathrm{GP} \\
(\mathrm{kN} / \mathrm{m} 2)\end{array}$} \\
\hline & & lebar $(\mathbf{c m})$ & panjang (cm) & & \\
\hline \multicolumn{6}{|l|}{ Alat Gali } \\
\hline PC 4000 & Komatsu & 120.00 & 670.00 & 2.45 & 240.34 \\
\hline EX3600 & Caterpilar & 127.00 & 666.00 & 2.12 & 208.12 \\
\hline EX2500 & Caterpilar & 100.00 & 612.00 & 2.03 & 199.50 \\
\hline PC 2000 & Komatsu & 81.00 & 578.00 & 2.18 & 190.00 \\
\hline PC 1250 & Komatsu & 70.00 & 499.50 & 1.53 & 149.63 \\
\hline
\end{tabular}

Tabel 2. Hasil analisis tebal layering alat gali muat di Lati menggunakan program Slide Rocscience 2018

\begin{tabular}{ccc}
\hline Unit & Tebal Layering Minimum $(\mathrm{m})$ & Faktor Keamanan \\
\hline PC 4000 & 4 & 1.112 \\
EX 3600 & $3-3.5$ & 1.156 \\
EX 2500 & $2.5-3$ & 1.200 \\
PC 2000 & 2.5 & 1.125 \\
PC 1250 & $1.5-2$ & 1.230 \\
\hline
\end{tabular}

Analisa dilakukan dengan pemodelan berdasarkan masing-masing ground pressure tiap unit yang bekerja dengan jarak minimum terhadap crest layering yaitu 2 meter dengan menggunakan program Slide Rocscience 2018. 


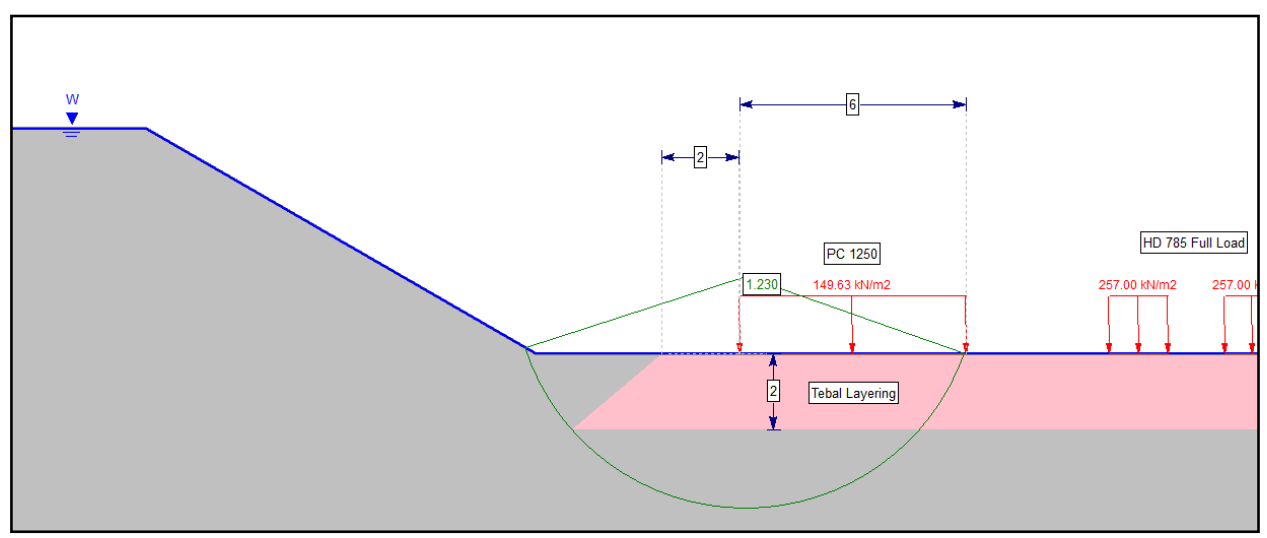

Gambar 4. Contoh Analisis Tebal layering PC 1250

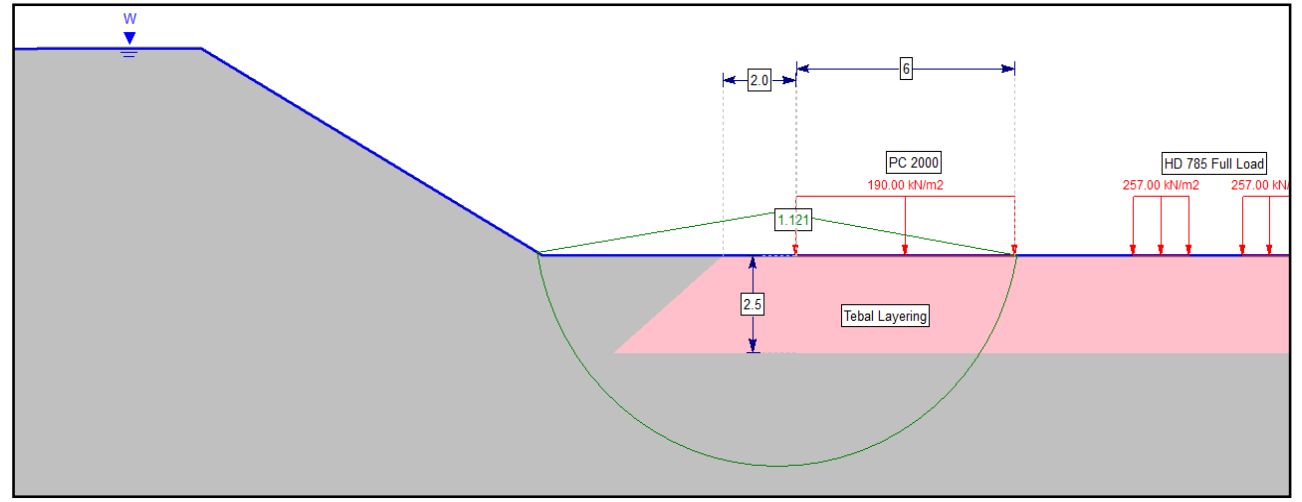

Gambar 5. Contoh Analisis Tebal layering PC 2000

Apabila diasumsikan terdapat material rawa dengan ketebalan 20 meter maka untuk metode lama dengan menggunakan PC 1250 diperlukan 6 tahapan loading dengan 5 diantaranya memerlukan layering, seperti gambar berikut

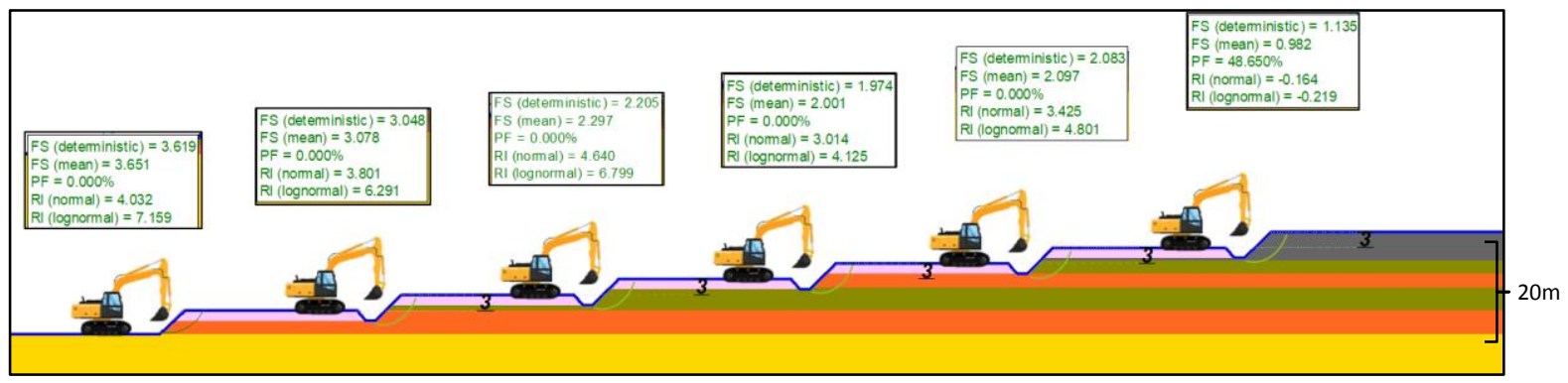

Gambar 6. Tahapan loading material lunak dengan metode lama (menggunakan PC 1250) dan ketebalan rawa 20 meter

\section{C.2 Spesifikasi Alat Muat dan Gali Komatsu}

Selain memiliki beban alat yang berbeda, PC 1250 dan PC2000 - PC 4000 memiliki Perbandingan Working Range dan tinggi kabin unit yang berbeda, sehingga memiliki tingkat keamanan terhadap potensial local failure yang berbeda ( PC 2000 memiliki tingkat keamanan yang lebih bAik terhadap potensi terjadinya longsoran yang bersifat lokal dibanding dengan PC 1250).

Table 3, spesifikasi alat Komatsu type backhoe

\begin{tabular}{|c|l|c|r|r|}
\hline \multicolumn{5}{|c|}{ Working Ranges } \\
\hline & ITEM & SATUAN & PC 1250SP-8 & PC 2000-8 \\
\hline A & Max. Digging height & $\mathrm{mm}$ & 13.000 & 13.410 \\
\hline B & Max. Dumping height & $\mathrm{mm}$ & 8.450 & 8.650 \\
\hline C & Max. Digging depth & $\mathrm{mm}$ & 7.900 & 9.235 \\
\hline D & Max. Vertical wall digging depth & $\mathrm{mm}$ & 5.025 & 2.710 \\
\hline E & Max digging depth of cut 2.440 mm level & $\mathrm{mm}$ & 7.745 & 9.115 \\
\hline F & Max. Digging reach & $\mathrm{mm}$ & 14.070 & 15.780 \\
\hline G & Max. Reach at ground level & $\mathrm{mm}$ & 13.670 & 15.305 \\
\hline
\end{tabular}




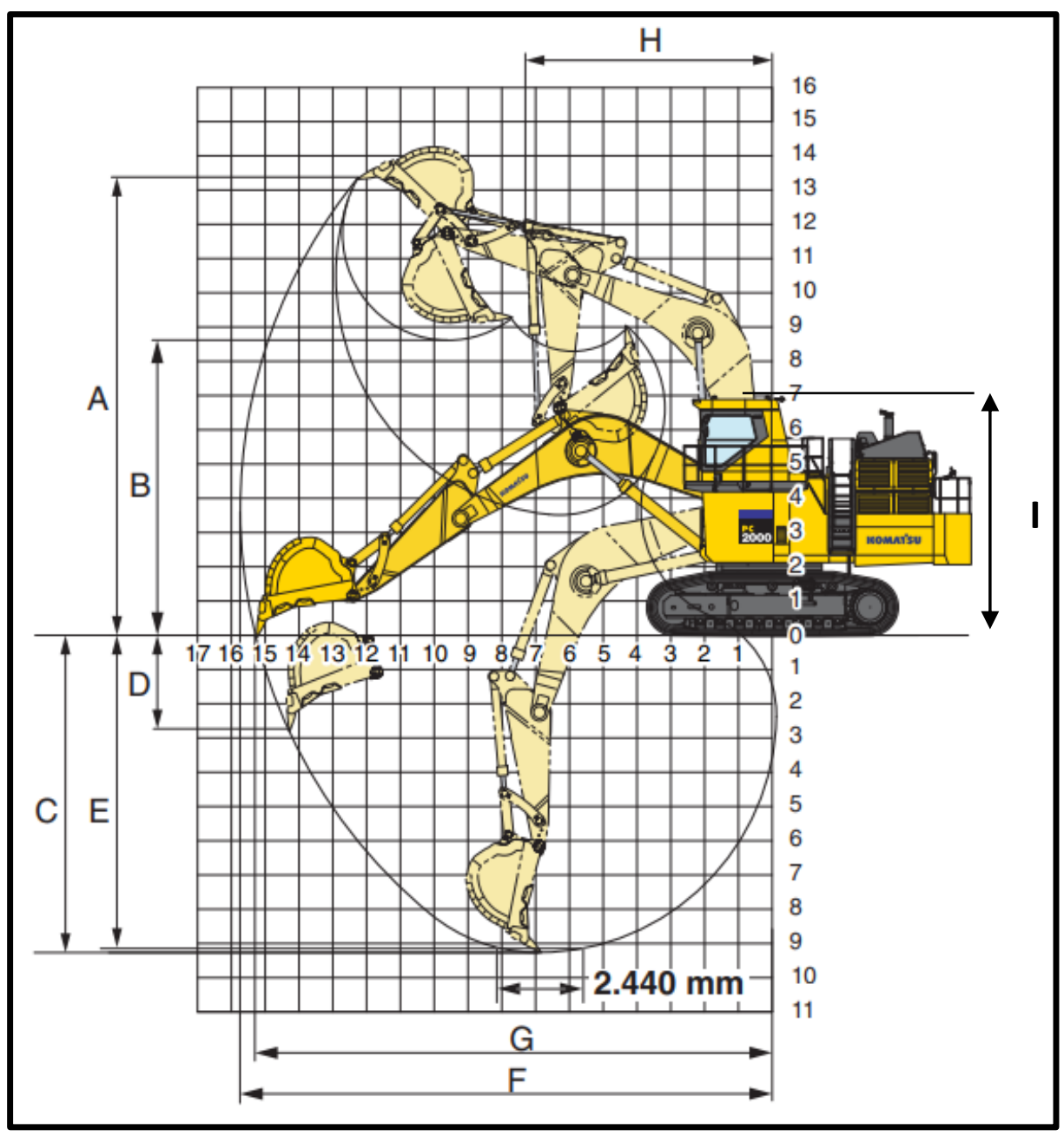

Gambar 7. Spesifikasi alat Komatsu type backhoe

\section{C.3 Hasil Korelasi Standard Penetration Test (SPT)}

Hasil korelasi data Standard Penetration Test (SPT) di Lati untuk plan tahun 2019 dapat dibagi menjadi 5 bagian yaitu dari top ke bottom: very soft (15 kPa), soft-firm $(25 \mathrm{kPa})$, firm-stiff $(50$ $\mathrm{kPa})$, soft-firm $(25 \mathrm{kPa})$ dan firm-stiff $(50 \mathrm{kPa})$ seperti pada gambar 8

\section{C.4 Metode Baru, Loading Rawa Menggunakan PC 2000, 2500, 3600 dan PC 4000}

Berdasarkan hasil pemboran SPT, spesifikasi alat yang digunakan dan analisis kebutuhan layering yang telah dijelaskan sebelumnya, maka dapat dilakukan re-analisis pemodelan loading material lunak dengan cara yang optimal, yaitu dengan membagi 3 stage pekerjaan : stage 1 (loading awal), stage 2 (layer ke 2 dan selanjutnya) dan stage 3 (layer terakhir).

\section{- Stage 1}

Merupakan loading awal material lunak yang berada di elevasi teratas (layer pertama material lunak). Berdasarkan hasil pemboran SPT profil material teratas memiliki properties 
material yang rendah, dicirikan dengan tekstur sangat lunak dan berair di lapangan. Unit excavator yang direkomendasikan untuk stage ini adalah sekelas PC 2000 dan PC 2500 dengan tebal material layering 2.5 - 3 meter. Geometri yang harus dibentuk pada stage ini adalah dengan beda tinggi maksimal $\leq 6 \mathrm{~m}(8.5 \mathrm{~m}$ termasuk layering) dan pembentukan slope dari track unit terhadap crest lereng dengan sudut $50^{\circ}$ (secara alami akan terbentuk, akibat soil properties yang rendah)

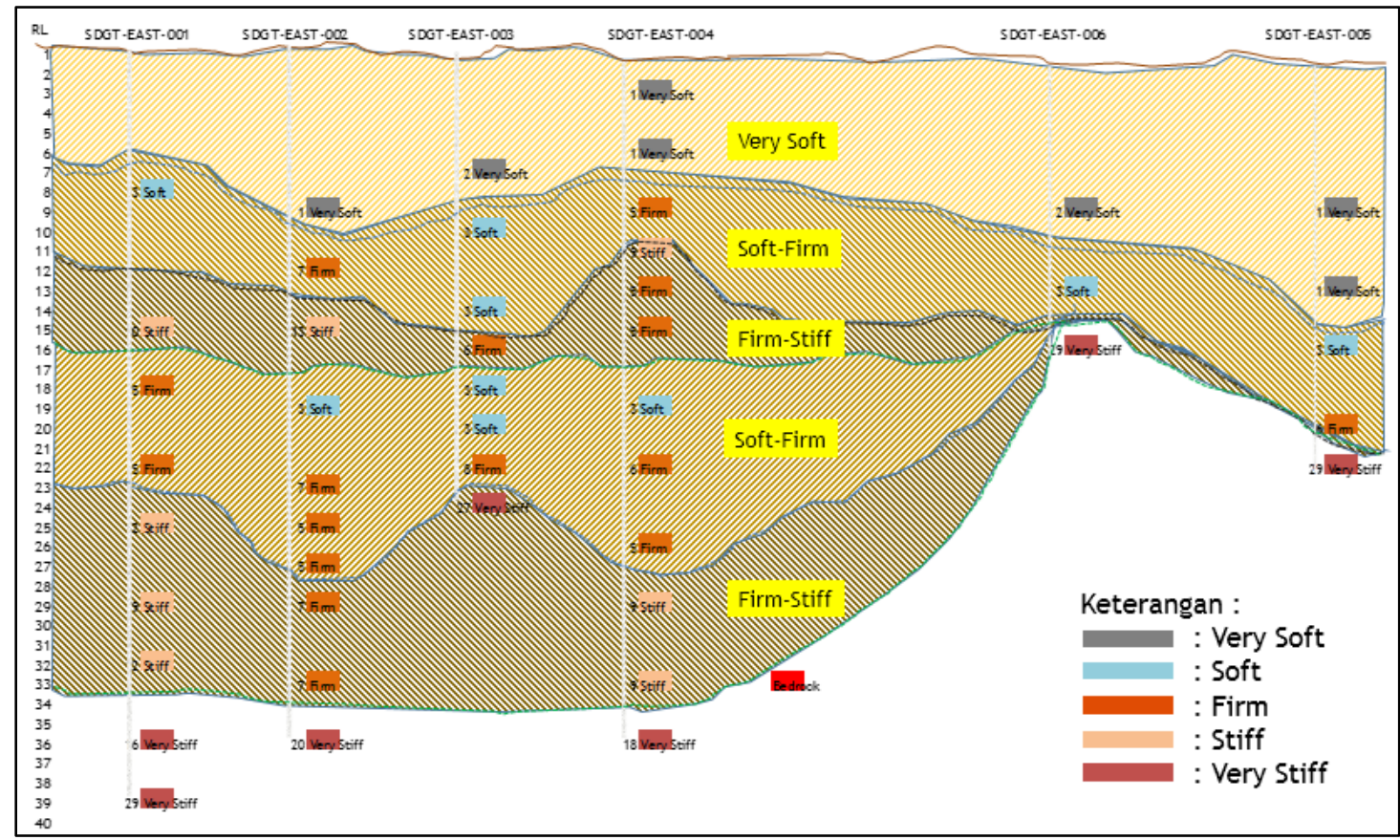

Gambar 8. Korelasi data SPT

\section{- Stage 2}

Pada stage ini merupakan layer kedua material lunak dimana memiliki strength material yang lebih tinggi dan lebih liat dibanding layer pertama. Unit excavator yang direkomendasikan untuk stage ini adalah sekelas PC 2000 dan PC 2500 dengan tebal material layering $2.5-3$ meter. Beda tinggi maksimal yang diperbolehkan yaitu $\leq 6 \mathrm{~m}(8.5 \mathrm{~m}$ termasuk layering) dan pembentukan slope dari track unit terhadap crest lereng dengan sudut $80^{\circ}$.

\section{- Stage 3}

Tahapan ini merupakan layer terakhir dari material lunak, yaitu kontak langsung dengan batuan insitu. Unit excavator yang direkomendasikan untuk stage ini adalah sekelas PC 3600 hingga PC 4000 dikarenakan tidak membutuhkan layering dan sudah berada pada batuan insitu. Sehingga beda tinggi maksimal yang diperbolehkan yaitu $\leq 8 \mathrm{~m}$ dengan sudut $80^{\circ}$.

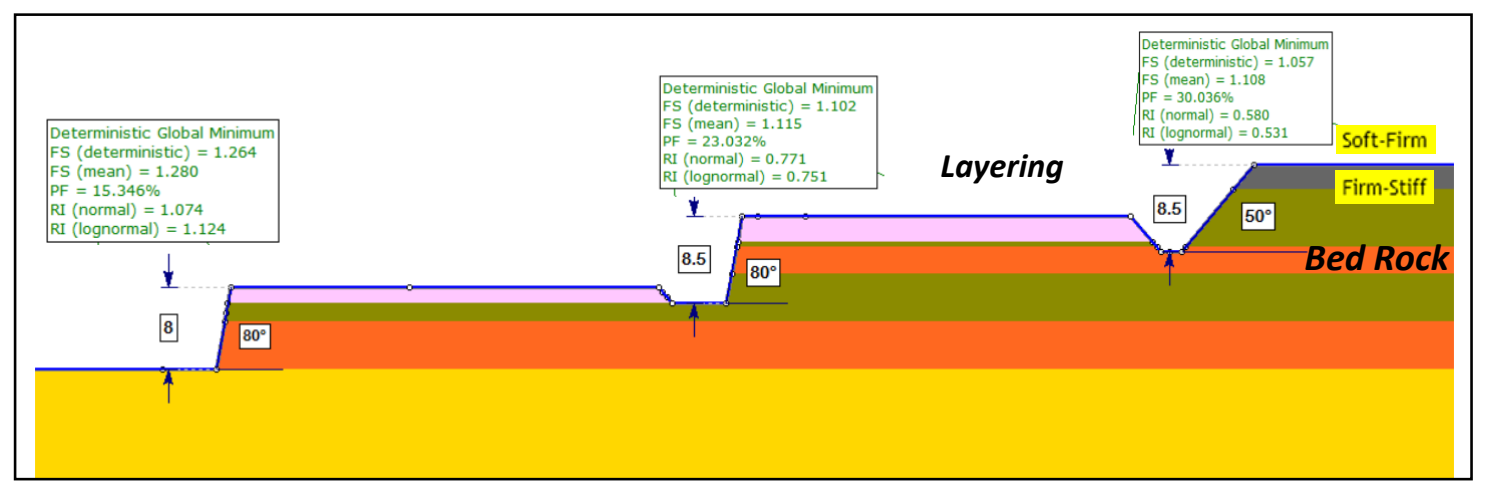


Gambar 9, Analisis geotecnik terhadap beda tinggi dan geometri loading material lunak

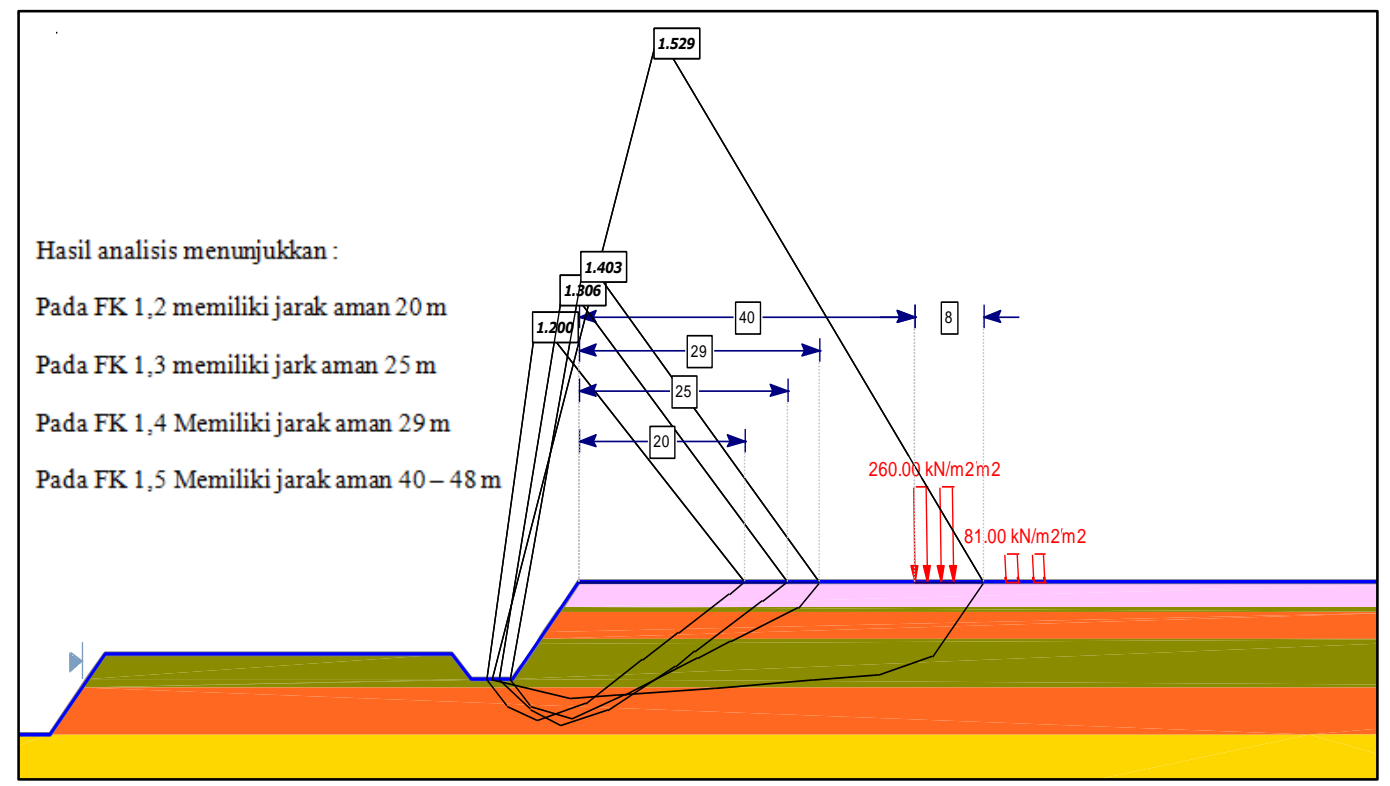

Gambar 10, Analisis Geotechnic jarak aman antara front loading rawa terhadap jalan dan/atau front loading yang berada di atasnya

Dari analisis geoteknik yang dilakukan dapat disimpulkan bahwa masih memungkinkan terjadi longsoran dengan sekala kecil (local failure) oleh karenanya perlu dilakukan kontrol resiko terhadap loading material lunak ini yaitu :

1. Memberi jarak 2.5-3m terhadap toe lereng agar terbetuk cekungan sebagai area steril jatuhan material

2. Menerapkan jarak aman 15 meter dari crest lereng rencana penggalian sebagai area steril kegiatan manusia

3. Menerapkan jarak aman antara front loading material lunak terhadap jalan dan/atau front loading lain yang berada di atasnya

4. Terdapat penanda batas kedalaman galian pada lengan unit excavator sebagai kontrol agar loader dapat mengukur kedalaman bucket pada saat menggali 
Gambar 11. Rencana penggalian dan kontrol resiko yang dilakukan

Trial metode baru loading material lunak dilakukan selama 2 bulan (Februari-Maret 2019) dan secara resmi telah diterapkân'thingga saat ini di Lati Main Operation, beberapa hal yang menjadi catatan yaitu: skill operatow, kondisi berair pada front loading material lunak serta dibutuhkan tambahan data pada area rawa yang belum dilakukan pemboran untuk mengakomodir plan jangka panjang

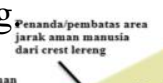
atas Rencana Area Aman :

$$
\substack{\text { Rasius } \\ \text { ridakx man }}
$$

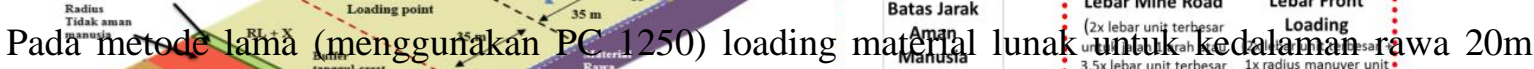
dibutuhkan layering sebanyàk $5 x$ di masing-masing beda elevasi, ședangkan metorde baru hanya

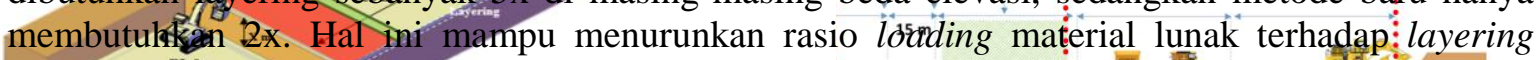
hingga 1:0.4 dan berdampak pada pengurangan kebutuhan volume layering secara langsung sehingga memiliki impact pada penggunaan fuel yang lebih efisiẹn. Jukaka dibandingkañ dengan rencana tahunan 2019 akan diperoleh penghematan volume dayer fing sebanyak 1.400 .000 BCM dan ber-impact pada penghematan fuel mencapai 1.447.179 litęP0. meter

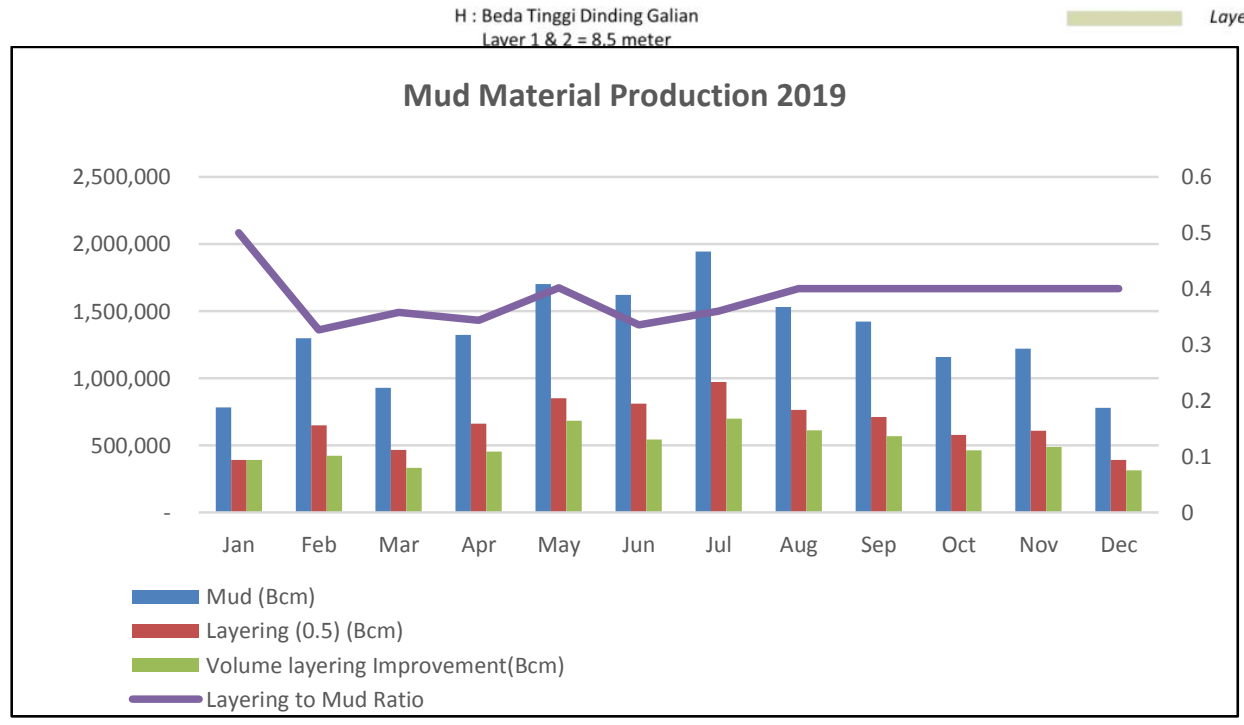

Gambar 12. Perbandingan volume material lunak terhadap tebal layering (data hingga bulan Juli 2019) 


\section{KESIMPULAN}

Perubahan metode loading material lunak dilakukan sesuai dengan kondisi penambangan yang sedang berlangsung terutama di site Lati. Penambahan data berupa pemboran Standart Penetration Test (SPT) dan Dynamic Cone Penetrometer (DCP) perlu dilakukan untuk mengatahui karakteristik material lunak di area Lati terhadap rencana penambangan jangka panjang (LOM). Hasil pemboran dapat dikategorikan menjadi beberapa karakteristik material lunak dari very soft hingga firm-stiff. Berdasarkan hasil pemboran tersebut, didapatkan 3 stage untuk loading material lunak dengan geometri masing-masing sesuai karakteristik material dan unit yang akan bekerja. Beberapa kontrol resiko dilakukan sebagai bentuk pengendalian diantaranya yaitu jarak terhadap toe lereng, jarak aman manusia, buffer terhadap jalan di sisi atas penggalian serta penanda pada lengan unit excavator perlu menjadi perhatian khusus untuk keselamatan operasional pertambangan. Dengan metode baru loading material lunak ini dapat menurunkan rasio loading terhadap layering hingga $1: 0.4$. Penurunan rasio volume material lunak terhadap layering ini berimpact kepada striping ratio, efisiensi fuel, dan percepatan pit development tahun 2019

\section{UCAPAN TERIMA KASIH}

Kami berterimakasih yang sebesar-besarnya atas dukungan semua pihak yang terlibat dalam penelitian ini yaitu PT. Berau Coal pada umumnya, Bapak Feri Indrayana selaku KTT PT Berau Coal dan mentor MMDP (Midle Management Program), Bapak Yan Adriansyah, Bapak Boby Rianto dan Bapak Arintoko serta keluarga besar tim G\&H Department, tim Lati Mine Operation dan PT Buma.

\section{DAFTAR PUSTAKA}

Anonim, 2009, Specifications \& Application Handbook. Edition 30. Komatsu Inc

Been, K. and Sills, G.C., 1981. Self-weighed consolidation of soft soils: an experimental and theoretical study. Geotechnique, Vol. 31 (4), 519-535.

Dankers, P.J.T., 2006. On the hindered settling of suspensions of mud and mud-sand mixtures.

DAS, Braja M. 1983. Advanced Soil Machanics. Mc Graw Hill

DAS, Braja M. 2006. Principles Geotechnical Engineering. Stamford Cengage Learning

G\&H Dept. 2018. Geotechnical Assessment Tebal layering proses loading material rawa Tambang Lati, PT.Berau Coal

G\&H Dept. 2019. Geotechnical Assessment Acuan beda tinggi loading material rawa Tambang Lati, PT.Berau Coal

Hoek, Evert and Bray, John, 1981, Rock Slope Engineering, Revised Third Edition, The Institution of Mining and Metallurgy, London.

Kiven, W. Chuck,1985, Peta Geologi Regional Berau, PT Berau Coal. 